\title{
Addition of binahong (Anredera cordifolia) leaf powder to diets to produce eggs with low cholesterol
}

\author{
Sri Kismiati (D), Hanny Indrat Wahyuni, Rina Muryani, Dwi Sunarti and Sri Sumarsih \\ Department of Animal Science, Faculty of Animal and Agricultural Science, Diponegoro University, Tembalang Campus, \\ Semarang, Central of Java, Indonesia. \\ Corresponding author: Sri Kismiati, e-mail: kismiati59@gmail.com \\ Co-authors: HIW: hihannyiw123@gmail.com, RM: muryani.rina@gmail.com, DS: dwisunarti@gmail.com, \\ SS: ssumarsih71@gmail.com \\ Received: 08-11-2019, Accepted: 20-02-2020, Published online: 31-03-2020
}

doi: www.doi.org/10.14202/vetworld.2020.604-608 How to cite this article: Kismiati S, Wahyuni HI, Muryani R, Sunarti D, Sumarsih S (2020) Addition of binahong (Anredera cordifolia) leaf powder to diets to produce eggs with low cholesterol, Veterinary World, 13(3): 604-608.

\begin{abstract}
Aim: The aim of this study was to evaluate the effect of the addition of binahong leaf powder to quail rations on the production and quality of eggs.

Materials and Methods: The study involved the use of two hundred 7-week-old quails housed evenly in 20 wire cages with a body weight of $123.77 \pm 0.72 \mathrm{~g}$. The quails were treated as follows: Ration without binahong leaf powder (T0), addition $2 \%$ of binahong leaf powder (T1), addition $4 \%$ of binahong leaf powder (T2), and addition $6 \%$ of binahong leaf powder (T3). The study used a completely randomized design. The parameters measured were the production, weight, and characteristics of the eggs, as well as the cholesterol, triglyceride, high-density lipoprotein (HDL), low-density lipoprotein (LDL), and egg protein content in the yolk.
\end{abstract}

Results: The addition of 2-6\% binahong powder did not significantly affect egg production, egg characteristics, or egg protein content, but significantly $(\mathrm{p}<0.05)$ affected the cholesterol, triglyceride, HDL, and LDL contents in yolk. The cholesterol, triglyceride, and LDL contents decreased significantly in T1, whereas HDL increased significantly in T2 and T3.

Conclusion: The addition of $2 \%$ binahong was enough to obtain healthy quail eggs with low levels of cholesterol, triglyceride, and LDL.

Keywords: binahong, cholesterol, high-density lipoprotein, low-density lipoprotein, triglyceride.

\section{Introduction}

Quail egg contains many high-quality nutrients but also high cholesterol [1]. The protein content in a quail egg is approximately $13.30 \%$ [1]. The cholesterol content in a quail egg is higher than in a chicken egg. The cholesterol content in the yolk of a quail egg is $6.79 \mathrm{mg} / \mathrm{dl}$, whereas the cholesterol content in chicken egg yolk is $4.03 \mathrm{mg} / \mathrm{dl}$ [2]. Overconsumption of cholesterol increases the blood cholesterol level, which leads to heart disease; thus, some people are afraid of consuming quail egg. Catapano and Wiklund [3] stated that blood cholesterol, particularly low-density lipoprotein (LDL) cholesterol, has a positive correlation with the occurrence of atherosclerosis. The consumption of high-density lipoprotein (HDL) derived from quail egg increases the blood serum HDL level and decreases atherosclerotic plaques in rabbits. Thus, egg HDL may be used as an anti-atherosclerotic agent for patients with cardiovascular disease [4]. An attempt to obtain quail egg with

Copyright: Kismiati, et al. Open Access. This article is distributed under the terms of the Creative Commons Attribution 4.0 International License (http://creativecommons.org/licenses/ by/4.0/), which permits unrestricted use, distribution, and reproduction in any medium, provided you give appropriate credit to the original author(s) and the source, provide a link to the Creative Commons license, and indicate if changes were made. The Creative Commons Public Domain Dedication waiver (http:// creativecommons.org/publicdomain/zero/1.0/) applies to the data made available in this article, unless otherwise stated. low cholesterol and high HDL contents needs to be carried out.

Binahong (Anredera cordifolia) is a wild plant with a rapid growth rate that requires no complicated cultivation; thus, binahong is abundant [5]. Sutrisno et al. [5] and Leliqia et al. [6] revealed that the leaf of binahong contains bioactive compounds, such as flavonoids, tannins, saponins, phenols, and steroids, and Astuti et al. [7] reported that the leaf also contains terpenoid, which may potentially increase pancreatic insulin secretion. Furthermore, Hasbullah [8] documented that binahong leaf exhibits hypolipidemic properties. Kamboh et al. [9] showed that supplementation with a bioflavonoid increases antioxidant and enzyme activities and decreases total cholesterol and triglyceride levels in the serum and breast meat of broiler. A study by Ouyang et al. [10] showed that supplementation with $15 \mathrm{mg} / \mathrm{kg}$ of alfalfa flavonoid increases HDL levels and decreases the levels of cholesterol, triglyceride, and serum LDL and the percentage of abdominal fat of broiler. Feeding saponin decreases cholesterol, insulin, and blood triglyceride and increases blood HDL synthesis. Saponin also decreases the contents of cholesterol [11] and protein digestibility [12] of broiler meat.

Based on the facts that binahong contain flavonoids, tannins, saponins, phenols, and steroids and it has potentially reduced cholesterol, triglyceride, LDL 
serum and increased HDL. Hopefully, it will produce a healthy egg product. Therefore, the aim of this study was to evaluate the effect of the addition of binahong leaf powder to rations on the contents of cholesterol, triglyceride, HDL, LDL, and protein in quail eggs.

\section{Materials and Methods}

\section{Ethical approval}

The procedure of using quail in this study has been approved by the Animal Ethics Committee in the Faculty of Animal Sciences, Diponegoro University, Semarang, Indonesia.

\section{Animals}

The study used two hundred 7-week-old female quails with an average body weight of $123.77 \pm 0.72 \mathrm{~g}$. The quails were housed in 20 wire cages. Each cage was $90 \times 35 \times 25 \mathrm{~cm}$ and housed 10 quails. The feed consisted of yellow corn, rice bran, pollard, poultry meat meal, soybean meal, $\mathrm{CaCO}_{3}$, salt, premix, and binahong leaf powder.

\section{Experimental design}

This study was arranged according to a completely randomized design with four treatments and five repetitions (10 quails per group per repetition). The treatment groups included T0, control ration (without binahong leaf powder); T1, control ration $+2 \%$ binahong leaf powder; $\mathrm{T} 2$, control ration $+4 \%$ binahong leaf powder; and $\mathrm{T} 3$, control ration $+6 \%$ binahong leaf powder in ration. The composition and nutrient content of the ration are presented in Tables- 1 and 2 .

\section{Tests and procedures}

The recording of egg production was carried out every day during the study and the formula:

Table-1: Feed composition of the control ration.

\begin{tabular}{lc}
\hline Feed ingredients & \% \\
\hline Yellow corn & 48.00 \\
Rice bran & 6.00 \\
Pollard & 16.00 \\
Poultry meat meal & 14.00 \\
Soybean meal $_{\mathrm{CaCO}_{3}}$ & 10.00 \\
Salt $_{\text {Premix }}$ & 5.50 \\
Total & 0.25 \\
\hline
\end{tabular}

Table-2: Nutrition content of the ration.

\begin{tabular}{lcccc}
\hline $\begin{array}{l}\text { Nutrient } \\
\text { contents }\end{array}$ & \multicolumn{4}{c}{ Addition of binahong leaf powder } \\
\cline { 2 - 5 } & T0 (0\%) & T1 (2\%) & T2 (4\%) & T3 (6\%) \\
\hline $\begin{array}{l}\text { Energy metabolic } \\
\text { (kkal/kg) }\end{array}$ & 2763.20 & 2694.12 & 2628.26 & 2565.40 \\
Protein (\%) & 19.77 & 19.35 & 18.95 & 18.56 \\
Fat (\%) & 4.66 & 4.58 & 4.51 & 4.43 \\
Crude fiber (\%) & 4.29 & 4.95 & 5.56 & 6.12 \\
Ca (\%) & 3.15 & 3.06 & 2.97 & 2.88 \\
P (\%) & 0.79 & 0.76 & 0.74 & 0.71 \\
Lysine (\%) & 0.96 & 0.93 & 0.89 & 0.86 \\
Methionine (\%) & 0.48 & 0.46 & 0.44 & 0.42 \\
\hline
\end{tabular}

Production $=($ number of eggs/number of quails $) \times$ $100 \%$ was used. Egg weight and egg characteristics were measured every 3 consecutive days weekly. The cholesterol, triglyceride, HDL, LDL, and protein contents in the egg yolk were collected by sampling one egg per experimental unit at the end of the study. The analyses of cholesterol and triglyceride contents were conducted based on the cholesterol p-aminophenazone method [13], HDL and LDL analysis was based on the enzymatic colorimetric method [13], and protein analysis was based on the Kjeldahl method [14].

\section{Statistical analysis}

Data were analyzed as a completely randomized design using one-way analysis of variance and Duncan's Multiple Range Test.

\section{Results and Discussion}

\section{Effect of the addition of binahong leaf powder on egg} production

The addition of $2-6 \%$ of binahong leaf powder, rich in flavonoids and saponins, did not significantly influence quail egg production at 8-14 weeks of age (Table-3). This result was similar to that reported by Kusumanti and Murwani [15], which showed that supplementation of binahong leaf powder does not significantly affect the egg production of laying hens. In line with this, Iskender et al. [16] showed that flavonoids have no significant effect on egg production. In contrast, supplementation with the quercetin flavonoid [17] and saponins derived from karaya increases the egg production of laying hens [18]. These inconsistencies may be caused by the differences in the levels of flavonoids and saponins used in the study, as well as the conditions of the study.

\section{Effect of binahong leaf powder on egg characteristics}

The addition of binahong leaf powder did not significantly affect the characteristics of the egg, including egg weight, yolk weight, albumen weight, and eggshell weight (Table-4). It has been hypothesized that the bioactive component of binahong leaf may positively affect the egg characteristics. However, this study revealed different results. According to Leke et al. [19], flavonoids of papaya seeds increase egg quality (egg yolk, albumen, and eggshell weight) of Indonesian hens. Moreover, Afrose et al. [18] reported that supplementation with 25,50 , and $75 \mathrm{mg} / \mathrm{kg}$ of karaya saponin increases egg weight, yolk weight, and albumen weight of laying hens, whereas Ayasan et al. [20] reported that supplementation of Yucca schidigera powder, with $120 \mathrm{ppm}$ of saponin, increases egg weight but does not affect the eggshell weight. As in our study, one study showed that supplementation with $0.2-0.6 \mathrm{~g} / \mathrm{kg}$ of flavonoid does not significantly influence egg quality [17]. In addition, supplementation with flavonoids does not significantly influence eggshell weight, as reported by Iskender et al. [16]. The differences in the nature and levels of bioactive compounds, the nutritional values of rations, and the conditions of study may be responsible for these divergent results. 
Table-3: Egg production on addition of binahong leaf powder in quail rations.

\begin{tabular}{lccccc}
\hline Age (weeks) & \multicolumn{3}{c}{ Addition of binahong leaf powder } & p-value \\
\cline { 2 - 5 } & T0 (0\%) & T1 (2\%) & T2 (4\%) & T3 (6\%) \\
\hline 8 & $29.71 \pm 2.74$ & $28.00 \pm 2.166$ & $28.85 \pm 2.74$ & $28.57 \pm 2.67$ & 0.49 \\
9 & $39.71 \pm 2.34$ & $42.28 \pm 1.91$ & $41.42 \pm 2.67$ & $41.14 \pm 2.55$ & 0.53 \\
10 & $45.14 \pm 4.58$ & $46.09 \pm 1.47$ & $47.23 \pm 2.34$ & $45.14 \pm 3.08$ & 0.57 \\
11 & $46.64 \pm 2.42$ & $49.49 \pm 1.38$ & $48.73 \pm 3.83$ & $47.63 \pm 1.73$ & 0.59 \\
12 & $56.38 \pm 2.49$ & $52.34 \pm 1.86$ & $54.50 \pm 1.37$ & $54.57 \pm 1.76$ & 0.67 \\
14 & $56.17 \pm 2.47$ & $57.55 \pm 1.45$ & $57.73 \pm 1.85$ & $58.74 \pm 1.93$ & 0.69 \\
\hline
\end{tabular}

Table-4: Influence of addition of binahong leaf powder on quail eggs characteristic.

\begin{tabular}{lccccc}
\hline Parameters & \multicolumn{3}{c}{ Addition of binahong leaf powder } & \multicolumn{2}{c}{ p-value } \\
\cline { 2 - 5 } & T0 (0\%) & T1 (2\%) & T2(4\%) & T3 (6\%) & \\
\hline Egg weight $(\mathrm{g})$ & $9.99 \pm 0.29$ & $10.01 \pm 0.11$ & $10.03 \pm 0.11$ & $10.03 \pm 0.27$ & 0.38 \\
Yolk weight (g) & $3.65 \pm 0.13$ & $3.92 \pm 0.25$ & $3.68 \pm 0.12$ & $3.93 \pm 0.17$ & 0.57 \\
Albumen weight (g) & $4.68 \pm 0.29$ & $4.53 \pm 0.18$ & $4.47 \pm 0.25$ & $4.60 \pm 0.19$ & 0.53 \\
Eggshell weight (g) & $1.14 \pm 0.28$ & $1.12 \pm 0.15$ & $1.14 \pm 0.17$ & $1.01 \pm 0.10$ & 0.32 \\
Yolk weight (\%) & $38.77 \pm 2.34$ & $41.80 \pm 2.72$ & $40.01 \pm 1.39$ & $41.13 \pm 0.79$ & 0.51 \\
Albumen weight (\%) & $49.63 \pm 2.78$ & $48.27 \pm 2.07$ & $48.56 \pm 2.70$ & $48.13 \pm 1.58$ & 0.73 \\
Eggshell weight (\%) & $11.43 \pm 2.73$ & $11.07 \pm 1.60$ & $11.41 \pm 1.73$ & $10.11 \pm 1.14$ & 0.12 \\
\hline
\end{tabular}

\section{Cholesterol, triglyceride, HDL, LDL, and protein con- tents in yolk}

The data on cholesterol, triglyceride, HDL, LDL, and protein contents in yolk after binahong leaf powder supplementation are shown in Table-5. The addition of $2 \%$ of binahong leaf powder decreased the level of cholesterol in the yolk of quail eggs $(\mathrm{p}<0.05)$. Flavonoids and saponins in the binahong leaf powder may inhibit cholesterol absorption; hence, cholesterol deposition may be reduced [21-23]. This is supported by Lien et al. [24] who showed that the consumption of flavonoids increases the excretion of cholesterol. In addition, flavonoids may increase reverse cholesterol transport (RCT), resulting in high cholesterol excretion; thus, there will be a lower cholesterol level in yolk. However, 4 and $6 \%$ binahong leaf powder did not affect the cholesterol level.

The addition of binahong leaf powder decreased the triglyceride content in quail yolk (Table-5). As shown in our study, supplementation with a flavonoid extracted from the root of Scutellaria baicalensis Georgi decreases triglyceride content in the serum of broiler [25]. Likewise, Kamboh and Zhu [21] and Ouyang et al. [10] reported that the consumption of flavonoids decreases the level of triglyceride in the serum and meat of broiler. According to Hsu and Yen [26] and Nagai et al. [27], flavonoids may inhibit intracellular triglyceride synthesis in the liver, which results in lower triglyceride deposition in quail egg yolk. In addition, flavonoid content in binahong leaf powder may increase the expression of peroxisome proliferator-activated receptor $\alpha$ in the liver, which is involved in lipid metabolism, especially fatty acid oxidation $[10,28]$.

The content of yolk HDL increased with the increased concentration of binahong leaf powder in the quail rations $(p<0.05)$. Similar to the result of our study, Afrose et al. [29] documented that saponins increase HDL content in broiler meat. Supplementation with karaya saponin also increases HDL content in quail egg [30]. Furthermore, Smith et al. [31] stated that supplementation with saponin extract increases the HDL content in the blood, liver, kidneys, and heart tissues of white mice. Kamboh and Zhu [21] reported that flavonoids increase the HDL content in serum and HDL deposition in the breast meat of broiler. The mechanism by which binahong leaf increased HDL concentration in quail egg yolk is not known; however, the role of binahong leaf powder in the RCT mechanism seems to be attributable to the increased HDL content in quail yolk. Millar et al. [23] and Marques et al. [32] reported that the increase in the RCT mechanism due to binahong leaf powder supplementation is accompanied by an increase in the level of HDL. Thus, this mechanism seems to be related to the contribution of HDL on RCT.

Treatment with binahong leaf powder decreased the level of LDL in the quail egg yolk (Table-5). Afrose et al. [30] reported that saponins decrease the LDL content of quail egg. Likewise, Chaudhary et al. [33] stated that saponins potentially decrease the LDL content of meat. In addition, supplementation with saponin extract decreases LDL content in the blood, liver, kidneys, and heart tissues of white mice [31]. Flavonoids have been reported to decrease the LDL level in the blood of broiler $[10,21,25]$. Furthermore, Zhou et al. [25] stated that flavonoid supplementation also decreases the LDL content of the breast meat of broiler. Binahong leaf extract contains saponins, which bind bile acid and form large mixed micelles. Cholesterol in the micelles cannot be absorbed by microvilli on the surface of intestinal epithelial cells, which causes a decrease in total and LDL cholesterol levels [34]. Saponins inhibit fat metabolism through 
Table-5: Influence of the addition of binahong leaf powder on cholesterol, triglyceride, $\mathrm{HDL}, \mathrm{LDL}$, and protein of quail egg yolk.

\begin{tabular}{lccccc}
\hline Parameters & \multicolumn{2}{c}{ Addition of binahong leaf powder } & \multicolumn{2}{c}{ p-value } \\
\cline { 2 - 5 } & T0 (0\%) & T1 (2\%) & T2 (4\%) & T3 (6\%) & $<0.01$ \\
\hline Yolk cholesterol $(\mathrm{mg} / \mathrm{g})$ & $56.15 \pm 5.04^{\mathrm{a}}$ & $23.77 \pm 3.75^{\mathrm{b}}$ & $51.97 \pm 4.63^{\mathrm{a}}$ & $51.35 \pm 7.55^{\mathrm{a}}$ & $<0.01$ \\
Yolk triglyceride $(\mathrm{mg} / \mathrm{g})$ & $903.22 \pm 58.21^{\mathrm{a}}$ & $608.62 \pm 22.46^{\mathrm{c}}$ & $778.34 \pm 53.59^{\mathrm{b}}$ & $811.63 \pm 104.01^{\mathrm{b}}$ & $<0.01$ \\
Yolk HDL $(\mathrm{mg} / \mathrm{g})$ & $36.86 \pm 1.32^{\mathrm{b}}$ & $34.8 \mathrm{~b} \pm 1.58^{\mathrm{b}}$ & $48.62 \pm 1.67^{\mathrm{a}}$ & $47.52 \pm 1.58^{\mathrm{a}}$ & $<0.01$ \\
Yolk LDL $(\mathrm{mg} / \mathrm{g})$ & $29.18 \pm 1.59^{\mathrm{a}}$ & $16.06 \mathrm{~b} \pm 0.33^{\mathrm{b}}$ & $17.09 \pm 0.37^{\mathrm{b}}$ & $16.28 \pm 0.36^{\mathrm{b}}$ & $<0.01$ \\
Protein of yolk $(\%)$ & $30.16 \pm 2.78$ & $30.37 \pm .82$ & $29.15 \pm 0.81$ & $30.19 \pm 2.55$ & 0.00 \\
\hline
\end{tabular}

Mean within a row for each parameter with different superscripts are significantly different $(p<0.01)$

the inhibition of lipase secretion and decrease cholesterol and LDL [35], but increase HDL [36], contents in the blood. Flavonoids are active compounds that reduce the activity of fatty acid synthase and reduce the level of LDL in animal tissues [10].

The addition of $2-6 \%$ binahong leaf powder did not significantly influence the protein content of egg yolk. This contrasted with a previous study. Iskender et al. [16] reported that supplementation with flavonoids (hesperidin, naringin, and quercetin) increases egg protein. Ahmad et al. [37] documented that bioactive compounds from Moringa oleifera leaf extracts increase the protein content in yolk.

In general, the protein content in an egg is derived from the feed. In this study, the inclusion of binahong leaf powder was accompanied by the decreased crude protein in the ration. Hence, the protein-increasing effect by binahong leaf powder seemed to be inhibited by lower protein content in the quail ration due to the binahong leaf inclusion.

\section{Conclusion}

The addition of $2 \%$ binahong leaf powder is best for lowering cholesterol, triglyceride, and LDL levels in quail egg.

\section{Authors' Contributions}

SK conducted the research, data collection, and drafting of the article. HIW developed the feeding concept and supervised the research, RM advised the experimental design, DS conducted data analysis, and SS performed laboratory analysis. All authors read and approved the final manuscript.

\section{Acknowledgments}

The authors are very grateful for the support of Poultry Production Laboratory, Faculty of Animal and Agricultural Sciences, Diponegoro University. The authors would like to thank Sugiharto S.Pt., for proofreading the manuscript.

\section{Competing Interests}

The authors declare that they have no competing interests.

\section{Publisher's Note}

Veterinary World remains neutral with regard to jurisdictional claims in published institutional affiliation.

\section{References}

1. Thomas, K.S., Jagatheesan, P.N.R., Reetha, T.L. and Rajendran, D. (2016) Nutrient composition of Japanese quail eggs. Int. J. Sci. Environ., 5(3): 1293-1295.

2. Uzochukwu, U.G., Vincent, E.O.O., Nwankwo, N. and Nicodemus, E.A. (2017) A comparative study on the total cholesterol, triacylglycerides and lipid concentrations of quail and chicken eggs. Int. J. Res. Pharm. Biosci., 4(10): 11-16.

3. Catapanoa, A.L. and Wiklund, O. (2015) Think again about cholesterol survey. Atheroscler. Suppl., 20: 1-5.

4. Eftekhar, S., Parsaei, H., Keshavarzi, Z., Yazdi, A.T., Hadjzadeh, M.A., Rajabzadeh, A. and Malayer, S.O. (2015) The prevention and treatment effects of egg yolk high density lipoprotein on the formation of atherosclerosis plaque in rabbits. Iran. J. Basic Med. Sci., 18(4): 343-349.

5. Sutrisno, E., Adnyana, I.K., Sukandar, E.Y. and Fidrianny dan Lestari, T. (2014) Study of wound healing and antibacterial activity of binahong (Anredera cordifolia (Ten.) Steenis, Centella asiatica (L.) Urban) and their combination of Staphylococcus aureus and Pseudomonas aeruginosa from diabetic wound patients. Bionatura-Jurnal Ilmu-ilmu Hayati dan Fisik, 16(2): 78-8

6. Leliqia, N.P.E., Sukandarv, E.Y. and Fidrianny, I. (2017) Overview of efficacy, safety and phytochemical study of Anredera cordifolia (Ten.) Steenis. Phamacol. Online, 1: 124-131. Available from: http://www.pharmacologyonline. silae.it. Retrieved on 15-08-2019.

7. Astuti, S.M., Sakinah, A.M.M., Andayani, B.M.R. and Risch, A. (2011) Determination of saponin compound from Anredera cordifolia (Ten) Steenis plant (Binahong) to potential treatment for several diseases. J. Agric. Sci., 3(4): 224-232.

8. Hasbullah, U.H.A. (2016) The content of saponin compounds in the leaves, stems and tubers of the Binahong plant (Anredera cordifolia (Ten) Steenis. Planta Trop. J. Agro Sci., 4(1): 20-24.

9. Kamboh, A.A., Arain, M.A., Mughal, M.J., Zaman, A., Arain, Z.M. and Soomro, A.H. (2015) Flavonoids: Health promoting phytochemicals for animal production-a review. J. Anim. Health Prod., 3(1): 6-13.

10. Ouyang, K., Xu, M., Jiang, Y. and Wang, W. (2016) Effects of alfalfa flavonoids on broiler performance, meat quality, and gene expression. Can. J. Anim. Sci., 96(3): 332-341.

11. Liu, T., Li, Z., Wang, T. and Zhu, X. (2016) Effects of alfalfa saponins on cholesterol metabolism in broilers. $J$. Nutr. Food Sci., 6(5): 1-5.

12. Das, T.K., Banerjee, D., Chakraborty, D., Pakhira, M.C., Shrivastava, B. and Kuhad, R.C. (2012) Saponin: Role in animal system. Vet. World, 5(4): 248-254.

13. Friedewald, W.T., Levy, R.I. and Frieddericson, DS. (1972) Estimation of the concentration of law density lipoprotein cholesterol plasma without use of the preparative ultracentrifugation. Clin. Chem., 18(6): 449-502.

14. Association of Official Analytical Chemists. (2005) Official Methods of Analysis of Association of Official Anality of Chemists. Association of Official Analytical 
Chemists, US. p80.

15. Kusumanti, E. and Murwani, R. (2018) Reduction of fecal parasites by Areca catechu L. Seed and Anredera cordifolia (Ten) Steenis leaves powder in laying hens. IOP Conf. Ser. Earth Environ. Sci., 116(1): 012102.

16. Iskender, H., Yenice, G., Dokumacioglu, E., Kaynar, O., Hayirli, A. and Kaya, A. (2017) Comparison of the effects of dietary supplementation of flavonoids on laying hen performance, egg quality and egg nutrient profile. Br. Poult. Sci., 58(7): 550-556.

17. Liu, H.N., Liu, Y., Hu, L.L., Suo, Y.L., Zhang, L., Jin, F., Feng, X.A., Teng, N. and Li, Y. (2014) Effects of dietary supplementation of quercetin on performance, egg quality, cecal microflora populations, and antioxidant status in laying hens. Poult. Sci., 93(2): 347-353.

18. Afrose, S., Hossaini, M.S. and Tsujii, H. (2010) Effect of dietary karaya saponin on serum and egg yolk cholesterol in laying hens. Br. Poult. Sci., 51(6): 797-804.

19. Leke, J.R., Mandey, J.S., Ratulangi, F., Rembet, G.D. and Junus, C.S. (2018) The effect of flavonoid papaya seed (Carica papaya $L$ ) in the organic feed on egg quality and eggshell of local chicken's hens. J. Nutr. Food Sci., 8: 44.

20. Ayasan, T., Sabri, Y., Mikail, B. and Sibel, C. (2005) The effects of dietary Yucca schidigera on egg yield parameters and eggshell quality of laying Japanese quails (Coturnix coturnix japonica). Int. J. Poult. Sci., 4(3): 159-162.

21. Kamboh, A.A. and Zhu, W.Y. (2013) Effect of increasing levels of bioflavonoids in broiler feed on plasma anti-oxidative potential, lipid metabolites, and fatty acid composition of meat. Poult. Sci., 92(2): 454-461.

22. Nekohashi, M., Ogawa, M., Ogihara, T., Nakazawa, K., Kato, H., Misaka, T., Abe, K. and Kobayashi, S. (2014) Luteolin and quercetin affect the cholesterol absorption mediated by epithelial cholesterol transporter niemann-pick C1-like-1 in caco-2 cells and rats. PLoS One, 9(5): e97901.

23. Millar, L., Duclos, Q. and Blesso, C.N. (2017) Effects of dietary flavonoids on reverse cholesterol transport, HDL metabolism, and HDL function. Adv. Nutr., 8(2): 226-239.

24. Lien, T.F., Yeh, H.S. and Su, W.T. (2008) Effect of adding extracted hesperetin, naringenin and pectin on egg cholesterol, serum traits and antioxidant activity in laying hens. Arch. Anim. Nutr., 63(1): 33-43.

25. Zhou, Y., Mao, S. and Zhou, M. (2019) Effect of flavonoid baicalein as a feed additive on the growth performance, immunity, and antioxidant capacity of broiler chicken. Poult. Sci., 98(7): 2790-2799.

26. Hsu, C.L. and Yen, G.C. (2007) Effects of flavonoids and phenolic acids on the inhibition of adipogenesis in 3T3-L1 Adipocytes. J. Agric. Food Chem., 55(21): 8404-8410.
27. Nagai, S., Matsumoto, C., Shibano, M. and Fujimori, K. (2018) Suppression of fatty acid and triglyceride synthesis by the flavonoid orientin through the decrease of $\mathrm{C} / \mathrm{EBP} \delta$ expression and inhibition of PI3K/Akt-FOXO1 signaling in adipocytes. Nutrients, 10(2): E130.

28. Wang, M., Xiao, F.L., Mao, Y.J., Ying, L.L., Zhou, B. and Li, Y. (2019) Decreases the triglyceride content through the PPAR signaling pathway in primary hepatocytes of broiler chickens. Biotechnol. Biotechnol. Equip., 33(1): 1000-1010.

29. Afrose, S., Hossain, M.S., Maki, T. and Tsujii, H. (2010) Hypocholesterolemic response to karaya saponin and Rhodobacter capsulatus in broiler chickens. Asian Aust. J. Anim. Sci., 23(6): 733-741.

30. Afrose, S., Hossaini, M.S. and Tsujii, H. (2011) Hypocholesterolemic effect of karaya saponin in Japanese laying quails (Coturnix coturnix japonica). J. Anim. Physiol. Anim. Nutr., 95(6): 693-700.

31. Smith, A.Y.R. and Adanlawo, I.G. (2013) Tissue lipid profile of rats administered saponin extract from the root of bitter kola. Adv. Biochem., 1(1): 1-4.

32. Marques, L.R., Diniz, T.A., Antunes, B.M., Rossi, F.E., Caperuto, E.C., Lira, F.S. and Gonçalves, D.C. (2018) Reverse cholesterol transport: Molecular mechanisms and the non-medical approach to enhance HDL cholesterol. Front. Physiol., 9: 526.

33. Chaudhary, S.K., Rokade, J.J., Aderao, N.G., Singh, A., Gopi, M., Mishra, A. and Raje, K. (2018) Saponin in poultry and monogastric animals: A review. Int. J. Curr. Microbiol. Appl. Sci., 7(7): 3218-3225.

34. Chávez-Santoscoy, R.A., Gutiérrez-Uribe, J.A. and SernaSaldívar, S.O. (2013) Effect of flavonoids and saponins extracted from black bean (Phaseolus vulgaris L.) Seed coats as cholesterol micelle disruptors. Plant Foods Hum. Nutr., 68(4): 416-423.

35. Zhao, H.L., Sim, J.S., Shim, S.H., Ha, Y.W., Kang, S.S. and Kim, Y.S. (2005) Antiobese and hypolipidemic effects of platycodin saponins in diet-induced obese rats evidences for lipase inhibition and calorie intake restriction. Int. J. Obes., 29(8): 983-990.

36. Annema, W. and Tietge, U.J.F. (2011) Role of hepatic lipase and endothelial lipase in high-density lipoprotein-mediated reverse cholesterol transport. Curr. Atheroscler. Rep., 13(3): 257-265.

37. Ahmad, S., Khalique, A., Pasha, T.N., Mehmood, S., Ahmad, S., Khan, A.M. and Hussain, K.V. (2018) Influence of Moringa oleifera leaf meal used as phytogenic feed additive on the serum metabolites and egg bioactive compounds in commercial layers. Braz. J. Poult. Sci., 20(2): 325-332.

\section{$* * * * * * * *$}

